DOI: 38136/jgon.987790

\title{
The Impact of Ethanol Sclerotherapy on ICSI Outcomes in Infertile Patients with Endometriomas Undergoing Controlled Ovarian Stimulation with GnRH Antagonist Protocol
}

\section{GnRH Antagonist Protokolü ile Kontrollü Overyen Hiperstimulasyon Öncesi Endometrioma Aspirasyonu ve Etanol Skleroterapisinin İntrasitoplazmik Sperm Enjeksiyonu Sonuçlarına Etkisi}

\author{
Lale Susan KARAKIS \\ Sabri CAVKAYTAR ${ }^{2}$ \\ Güvenç KARLIKAYA \\ Mustafa BAHCECI
}

(1) Orcid ID:0000-0003-1870-5415
(1) Orcid ID:0000-0003-1584-8568
(1) Orcid ID:0000-0002-0366-1037
(1) Orcid ID:0000-0002-5626-3251

\section{${ }^{1}$ Bahçeci Fulya Tüp Bebek Merkezi, Kadın Hastalıkları ve Doğum, Istanbul, Türkiye \\ ${ }^{2}$ Bahçeci Umut Tüp Bebek Merkezi, Kadın Hastalıkları ve Doğum, İstanbul, Türkiye}

\section{ÖZ}

Amaç: Bu çalismanın amacı endometrioması olan infertil hastalarda kontrollü overyen hiperstimülasyon öncesi endometrioma aspirasyonu ve etanol ile skleroterapi işleminin ICSI sonuçlarına olumlu etkisi olup olmadığını araştırmaktır.

Materyal ve Metod: $\mathrm{GnRH}$ antagonist protokolü ile kontrollü overyen stimulasyon tedavisi öncesi endometrioma aspirasyonu yapılan 103 hasta ile endometrioma aspirasyonu yapıımayan 405 hastanın siklus özellikleri ve gebelik sonuçları retrospektif olarak karşılaştırıldı.

Bulgular: Iki grup arasında toplanan oosit sayisi, metafaz II oosit sayisi, fertilizasyon oranları ve iyi kaliteli embriyo oranlarında istatistiksel olarak anlamlı bir fark saptanmadı. Klinik gebelik oranları, implantasyon oranları ve canlı doğum oranlarında da iki grup arasında anlamlı bir fark bulunmadı. Skleroterapi uygulanan grupta intraperitoneal kanama, peritonit, overyen abse veya intestinal perforasyon gibi majör herhang bir komplikasyon izlenmedi.

Sonuç: Bu çalışmada GnRH antogonist protokolü ile kontrollü overyen stimulasyondan hemen önce yapılan endometrioma aspirasyonu ve etanol ile skleroterapi işleminin ICSI sonuçlarına olumlu bir etkisi saptanamamıştır. Bunun yanında literatürde etanol skleroterapisinin $\mathrm{GnRH}$ agonist protokolleri ile uygulandığı taktirde daha olumlu sonuçlar verebileceğine dair yayınlar mevcuttur. Kolay uygulanabilen ve komplikasyon oranı düşük olan bu prosedürün yumurta toplama işlemini zorlaştıracak büyüklükte endometrioması olan veya şiddetli ağrı şikayeti olan hastalarda cerrahiye alternatif olarak kullanılması önerilebilir.

Anahtar kelimeler: etanol skleroterapisi , endometrioma aspirasyonu, infertilite, tüp bebek tedavisi

\section{INTRODUCTION}

Endometriosis, defined the presence of endometrial glands and stroma outside of the uterine cavity, is encountered in $25-50 \%$ of women with infertility $(1,2)$. Endometriosis is thought to cause infertility through distortion of tubal anatomy, ovarian damage, altered endometrial receptivity and impai-

\section{ABSTRACT}

Objective: The aim of the study was to determine whether endometrioma aspiration and alcohol sclerotherapy performed prior to controlled ovarian stimulation has any beneficial effects on ICSI outcomes in patients with endometriomas.

Materials and Methods: The cycle characteristics and pregnancy outcomes of 103 patients with endometriomas who underwent ethanol sclerotherapy on day 2 of the controlled ovarian stimulation with a gonadotropin antagonist protocol were retrospectively compared with the cycle characteristics of 405 patients with endometriomas who did not receive scleroterapy before stimulation.

Results: No statistically significant difference was observed in the number of retrieved oocytes, metaphase II oocytes, fertilization and good quality embryo rates between the two groups. The clinical pregnancy rate, implantation rate and live birth rates were similar among the two groups. No major complications including intraperitoneal haemorrhage, peritonitis, ovarian abscess or intestinal perforation were recorded.

Conclusion: The results of the present study indicate that ethanol sclerotherapy does not improve ICSI outcomes when performed right before ovarian stimulation and without concomittant $\mathrm{GnRH}$ analogue administration. Since it is a simple outpatient procedure without significant complications, ethanol sclerotherapy may be performed prior to IVF as an alternative to surgery to improve the accessibility of follicles and monitoring of follicle growth in patients with large endometriomas and for those patients with intractable pain symptoms, without decreasing the ovarian reserve.

Keywords: ethanol sclerotherapy, endometrioma, aspiration, IVF, infertility

red sperm-oocyte interaction as a result of chronic intrapelvic inflammation and fibrosis(3-5).Women with ovarian endometriosis undergoing treatment with assisted reproductive technologies (ART) have been shown to have a higher likelihood of decreased ovarian reserve, reduced oocyte quality, low response to controlled ovarian stimulation and higher cycle 
cancellation rates when compared to women without endometriomas $(6,7)$. The mechanical pressure of the endometrioma on ovarian tissue is thought to compromize follicle development by decreasing intraovarian blood flow and reducing the space for follicle growth(8). The inflammation and oxidative stress mediated by the ectopic endometrial tissue is thought to damage follicles and interfere with oocyte maturation(9-11). Furthermore, the presence of large endomertriomas have been shown to interfere with follicle monitorization during ovarian stimulation and hamper access to follicles during the oocyte pickup procedure(8). In an effort to reduce the negative impact of endometriomas on in vitro fertilization(IVF) outcomes, surgical excision prior to ART has been performed widely in the recent past(1214). However, since it was shown in recent years that it resulted in decreased ovarian reserve without improving IVF outcomes, surgical endometrioma excision has been restricted to be used only in the presence of a large endometrioma likely to hamper oocyte retrieval or if the patient is suffering from severe pain symptoms(15-18).

Ultrasound guided aspiration of endometriomas with sclerotherapy has emerged as a less invasive alternative to surgery to improve in vitro fertilization outcomes without decreasing ovarian reserve(19-21). Endometrioma sclerotherapy involves the aspiration of the fluid within the endometrioma, followed by the injection of a sclerosing agent into the cyst cavity. The injected agent may then be reaspirated or left to retain inside the cyst. Sclerosing agents are thought to act by damaging the epithelial lining of the cyst by inducing inflammation and fibrosis(22). Agents such as methotrexate, ethanol and tetracycline have been reported in the literature to be effective in reducing endometrioma recurrences when injected inside the cyst cavities(23-26). However studies on the ability of sclerotherapy in improving IVF outcomes when performed before controlled ovarian stimulation have provided controversial results.

In the present study we aimed to present our 6 year experience on endometrioma aspiration and alcohol sclerotherapy performed prior to controlled ovarian stimulation and determine if this procedure has any beneficial effects on IVF outcomes.

\section{MATERIALS AND METHODS}

The medical records of infertile patients diagnosed with endometrioma who underwent contolled ovarian stimulation at the Fulya Bahceci IVF Centre in Istanbul between January 2013 and January 2019 were reviewed retrospectively. The approval of the Uskudar University ethics committee was obtained.
The inclusion criteria for the study were: age between 20 and 40 , a body mass index (BMI) of 18 to $30 \mathrm{~kg} / \mathrm{m} 2$, regular menstrual cycle lengths of 21-35 days, the presence of unilateral or bilateral endometriomas with a minimum mean size of $25 \mathrm{~mm}$ on transvaginal ultrasonography detected on at least two occasions.

The typical ultrasound features used to define an endometrioma were the presence of a homogeneous hypoechoic appearing unilocular cystic mass with diffuse internal echoes. Patients with ultrasonographic features suggestive of cysts other than endometriomas(including solid components, septations, papillary projections, calcifications), those with a prior history of endometrioma resection or additional causes of infertility such as polycystic ovary syndrome, severe male factor infertility or chromosome abnormalities were excluded from the study. Only the first stimulation cycles of each patient at the centre were included in the analyses.

At our centre, endometrioma aspiration and alcohol scleroterapy prior to controlled ovarian stimulation is offered to patients by certain infertility specialists with the aim of improving ART results, while other specialists do not practice this intervention. Patients who chose to undergo endometrioma aspiration and alcohol sclerotherapy before stimulation were placed in group 1 and those who did not undergo endometrioma aspiration were placed in group 2 .

Vaginal endometrioma aspiration was performed under general anesthesia on day 2 or 3 of the menstrual period. After disinfection of the vagina with povidone solution a 16 gauge $33 \mathrm{~cm}$ needle was inserted through the guide of a transvaginal ultrasound probe into the endometrioma cavity and the contents were aspirated. The cyst cavity was flushed with $95 \%$ alcohol solution and aspirated several times. All patients received antibiotic prophylaxis with $1 \mathrm{~g}$ oral azithromycin on the day of aspiration.

Controlled ovarian stimulation using the gonadotropin releasing hormone $(\mathrm{GnRH})$ antagonist protocol was initiated on the same day as the endometrioma aspiration. Recombinant human FSH(Gonal-F® 900IU; Serono, France) plus Merional, and Cetrotide were used for ovarian stimulation. Ovulation was triggered using recombinant human chorionic gonadotrophin(HCG; Ovitrelle®; Serono, France) with or without $0.1 \mathrm{IU}$ of gonapeptyl. Medication doses were adjusted according to the age, BMI and ovarian reserve of patients. Oocytes were retrieved under transvaginal ultrasound guidance 35 hours after triggering of ovuation. Mature oocytes were fertilized by intracytoplasmic 
morphologically selected sperm injection(IMSI). Embryo quality was assessed on days 2, 3, 4, 5, or 6 following oocyte pick up and all transferrable embryos were frozen. The stage(cleavage or blastocyst stage) at which the embryos were frozen was determined depending on the number and quality of available embryos.

Cleavage stage embryos were graded according to the Istanbul consensus(27). Blastocyst stage embryos were scored according to the Gardner and Schoolcraft grading system(28). The embryos were considered suitable for cryopreservation on the 5 th or 6th day if they were full or expanded blastocysts with a type $A$ to $C$ inner cell mass and a type $A$ to $C$ trophectoderm.

Cleavage stage embryos were considered to be good quality if the blastomeres were uniform and had less than $20 \%$ fragmentation. Embryos with uneven blastomeres or fragmentation of at least $20 \%$ were considered to be of moderate quality. Blastocysts were considered to be good quality if they were fully expanded and the inner cell mass and trophoectoderm were type $A$ or type $B$. All blastocysts with type $C$ inner cell mass or trophoectoderm were considered to be of moderate quality.

All patients underwent frozen-thawed embryo tranfers following hormonally prepared cycles. Oral estradiol(E2, $4 \mathrm{mg} / \mathrm{d}$ ) was initiated in a sequential step-up regime on the 2 nd day of the menstrual period, with dose increments of $2 \mathrm{mg}$ every four days, up to a maximum dose of $8 \mathrm{mg} /$ day. Patients underwent ultrasound examination and serum progesterone(P4) measurements on the 12th or 13th day of E2 treatment. Intramuscular progesterone $100 \mathrm{mg} /$ daily was initiated if the serum P4 level was below $1.5 \mathrm{pg} / \mathrm{dl}$ and the endometrial lining appeared trilaminar with a thickness ranging between 7 to $14 \mathrm{~mm}$. Blastocysts were transferred on the 6thday of progesterone exposure.

The vitrification and warming procedures were performed using commercial vitrification kits(Vit Kit@-Freeze, 90133-SO and Vit Kit@-Thaw, 90137-SO, Irvine Scientific, CA, USA). The thawed embryos were assessed for viability and were transferred under ultrasound guidance using soft catheters.

Serum beta-human Chorionic Gonadotropin( $\beta$-hCG) levels were measured 12-15 days following embryo transfer. If the pregnancy test was positive, oral E2 was continued until a fetal heartbeat was visible on ultrasound and intramuscular progesterone was administered until 10 weeks of gestation.

The primary outcome of the study was the implantation rate defined as the number of gestational sacs on ultrasound at 4-5th weeks of gestation divided by the number of embryos transferred. Secondary outcomes were the clinical pregnancy rate and live birth rate defined as the presence of a fetal heart beat at 6-7th weeks of gestation and live birth of a neonate after 24 weeks of gestation, respectively. Ongoing pregnancy was defined as fetal heart activity and adequate growth at 12 weeks of gestation.

\section{Statistical analyses}

Data were analysed using the Statistical Package for the Social Sciences software(IBM version 21.0, USA). The normality of data was evaluated using histograms and Kolmogorov-Smirnov test. Mann-Whitney $U$ test was performed to compare continuous variables that were not distributed normally. Fisher exact or Pearson's chi-square test was performed to compare categorical variables. A p value below 0.05 was considered to be statistically significant. Data are given as median(range), median(25th-75th percentile), or number(percentage).

\section{RESULTS}

A total of 553 patients were included in the study, 103 of whom underwent endometrioma aspiration with ethinyl alcohol sclerotherapy prior to stimulation. The remaining 405 patients underwent ovarian stimulation without prior endometrioma aspiration.

The median age of patients involved in the study was 35 years and the average duration of infertility was 4 years. Out of the 553 patients involved in the study, 343 had unilateral, and 210 had bilateral endometriomas. The clinical characteristics of patients are shown in Table 1. There were no significant differences in the age, duration of infertility, BMI, antral follicle count(AFC) or size of endometriomas between the two groups. 
Table 1. Comparison of patient characteristics

\begin{tabular}{|c|c|c|c|}
\hline & $\begin{array}{c}\text { Aspiration Group } \\
(\mathbf{n}=103)\end{array}$ & $\begin{array}{c}\text { Control Group } \\
(\mathbf{n}=450)\end{array}$ & $\mathbf{p}$ \\
\hline Age (years) & $35(30-38)$ & $35(31-38)$ & NS \\
\hline Body mass index (kg/m²) & $23.5(21.4-26.3)$ & $23.6(21.4-27.1)$ & NS \\
\hline Duration of infertility (years) & & & \\
\hline Antral follicle count & $4(3-6)$ & $4(3-5)$ & NS \\
\hline Size (mm) & $9(6-13)$ & $9(5-14)$ & NS \\
\hline Bilateral endometriomas & $4(3.5-4.5)$ & $4(3.5-4.5)$ & NS \\
\hline Bnilateral \% (n) & $64.1 \%(66)$ & $61.6 \%(277)$ & NS \\
\hline Bilateral \% (n) & $35.9 \%(37)$ & $38.4 \%(173)$ & \\
\hline
\end{tabular}

All values are median (25th-75th percentile).

NS: Not significant $(p>0.05)$

The median diameter of endometriomas in the aspiration group were $4 \mathrm{~cm}$ in both the aspiration and the nonaspiration groups.

Out of the 103 patients in the aspiration group, 20 patients' cycles were cancelled. In the nonaspiration group, 100 cycles out of 450 had to be cancelled. The cycle cancellation rates and reasons for cancellation are presented in Table 2.

Table 2. Comparison of cancellation rates between the groups.

\begin{tabular}{|r|c|c|c|}
\hline & $\begin{array}{c}\text { Aspiration Group } \\
(\mathbf{n}=\mathbf{1 0 3})\end{array}$ & $\begin{array}{c}\text { Control Group } \\
(\mathbf{n}=\mathbf{4 5 0})\end{array}$ & $\mathbf{p}$ \\
\hline Cancellation rate & $22.3 \%$ & $21.1 \%$ & NS \\
\hline Reasons for cancellation & & $2.9 \%$ & \\
No retrieved oocytes & $7.8 \%$ & $1.3 \%$ & NS \\
No metaphase-2 oocytesi & $2.9 \%$ & $6.4 \%$ & \\
Fertilization Failure & $2.9 \%$ & $10.5 \%$ & \\
Cleavage arrest & $8.7 \%$ & & \\
\hline
\end{tabular}

NS: Not significant $(p>0.05)$

The ART outcomes were compared between patients who underwent embryo transfers. Comparison of ART outcomes are shown in Table 3. No statistically significant difference was observed in the number of retrieved oocytes, metaphase II oocytes, fertilization and high quality embryo rates. The clinical pregnancy rate, implantation rate, clinical pregnancy rate and live birth rates were similar among the two groups.
Table 3. Comparison of in vitro fertilization (IVF) treatment outcomes.

\begin{tabular}{|r|c|c|c|}
\hline & & & \\
\hline & $\begin{array}{c}\text { Aspiration Group } \\
(\mathbf{n}=\mathbf{8 3})\end{array}$ & $\begin{array}{c}\text { Control Group } \\
(\mathbf{n}=\mathbf{3 5 0})\end{array}$ & $\mathbf{p}$ \\
\hline $\begin{array}{r}\text { Embryo transfer day } \\
\text { Embryo transfer day (2-4) }\end{array}$ & $22.9 \%$ & $27.4 \%$ & \\
Embryo transfer day (5-6) & $77.1 \%$ & $72.6 \%$ & \\
\hline Embryo quality & & & $\mathrm{NS}$ \\
\hline Mood & $44.6 \%$ & $43.2 \%$ & \\
\hline Moderate & $55.4 \%$ & $56.8 \%$ & \\
\hline Double embryo transfer rate & $25.3 \%$ & $30.6 \%$ & $\mathrm{NS}$ \\
\hline Number of retrieved oocytes* & $8(1-28)$ & $10(1-26)$ & $\mathrm{NS}$ \\
\hline Number of MII oocytes* & $7(1-23)$ & $8(1-26)$ & $\mathrm{NS}$ \\
\hline Number of 2PN embryos* & $5(1-21)$ & $6(1-25)$ & NS \\
\hline Clinical Outcomes & & & \\
Positive Beta-hCG rate & $67.5 \%$ & $70.3 \%$ & NS \\
Implantation rate & $60.2 \%$ & $61.7 \%$ & NS \\
Clinical pregnancy rate & $56.6 \%$ & $58.6 \%$ & NS \\
Live birth rate & $51.8 \%$ & $52 \%$ & NS \\
\hline
\end{tabular}

*Values are median (range).

NS: Not significant $(p>0.05)$

No major complications including intraperitoneal haemorrhage, peritonitis, ovarian abscess or intestinal perforation were recorded.

\section{DISCUSSION}

In the present study, no difference could be detected in the IVF outcomes between patients with endometriomas who underwent aspiration with alcohol sclerotherapy and those who did not receive any intervention.

A recent metaanalysis investigating the effect of sclerotherapy on reproductive outcomes failed to find statistically significant differences in the number of retrieved oocytes and clinical pregnancy rates between patients who underwent endometrioma sclerotherapy and those who received no intervention(29). Endometrioma recurrence rate was reported to be $0-13.3 \%$ when ethanol was left to retain in the cavity after aspiration of the cyst and $0-62.5 \%$ when the alcohol was withdrawn after $0-15$ minutes. Pain symptoms were improved in $68-96 \%$ of patients who underwent sclerotherapy. The authors concluded that sclerotherapy for endometriomas is equal in effectiveness to laparoscopic cystectomy with respect to endometrioma recurrence and pain relief and may be useful for patients with pain symptoms planning to conceive, eventhough no benefit was detected with respect to IVF outcomes.

Aflatoonan et al conducted a randomized controlled study com- 
paring the clinical pregnancy, implantation and fertilization rates between patients with endometriomas who underwent ethanol sclerotherapy 3 months prior to IVF treatment and a control group of patients who did not receive sclerotherapy(30). All recruited patients had presented with recurring endometriomas larger than $3 \mathrm{~cm}$ following a history of surgical excision. In the study group, $98 \%$ alcohol was instilled into the endometrioma and was left in situ for 10 minutes before being aspirated from the cavity. No clinically significant difference was observed between the two groups with respect to IVF outcomes.

Guo et al retrospectively compared IVF outcomes in a group of patients who underwent 1 to 3 endometrioma aspirations over a period of 2 months prior to IVF with a control group of patients who did not undergo endometrioma aspiration(31). No sclerosing agents were injected following endometrioma aspiration; however, a long acting $\mathrm{GnRH}$ agonist was administered before aspiration which was repeated one month later when necessary in both groups. In contrast to the aforementioned studies, Guo et al found the number of retrieved oocytes, fertilized mature oocytes, high-quality embryos, implantation rates and clinical pregnancy rates to be statistically significantly higher in the study group than the control group. This may be attributed to the combined effect of $\mathrm{GnRH}$ agonist suppression and aspiration for up to 3 times until the endometrioma size decreased considerably. Also performing IVF treatment two or more months after the procedure may have helped to improve the results by allowing sufficient time for sclerotherapy to have a more profound effect.

Similarly, Miguel et al reported improved cumulative live birth rates in patients with moderate to severe endometriosis who underwent ethanol sclerotherapy before IVF using an ultralong agonist protocol, compared to those who did not have sclerotherapy before treatment(32). In their study $96 \%$ ethanol was injected into the cyst cavity, with complete reaspiration after 10 minutes of retention. They hypothesized that endometrioma sclerotherapy before an ultralong agonist protocol may increase embryo implantation rates.

At 12 months of follow up Hsieh reported a $36 \%$ and $69 \%$ decrease in the size of endometriomas and a $49.5 \%$ and $60.8 \%$ increase in the antral follicle count of patients who underwent ethanol sclerotherapy with either irrigation or retention, respectively(8). This may be especially important for patients with dimished ovarian reserves in whom even the slightest improvement in the athral follicle count may be crucial for successful pregnancy.

In the literature, complications such as abdominal pain $(1.8 \%$ $15.3 \%)$, postoperative fever $(5.5 \%)$, alcohol intoxication (3.8\%), and intracystic abscess( $2 \%$ ) have been reported after sclerotherapy(29). In the present study, no complications were encountered in line with a number of previous studies $(23,24)$. Preoperative antibiotic administration, intracystic alcohol instillation and use of a sterile technique are likely to have prevented the occurrence of such complications.

One of the limitations of the study is its a retrospective nature and that details concerning pain scores and $\mathrm{AMH}$ (antimüllerian hormone) levels before and after the procedure were not available for all patients. Therefore we were not able to report on endometrioma recurrence rates or the effect of sclerotherapy on pain management. Secondly, since only the first IVF cycle following the procedure was used for analysis, the long term or cumulative effects of sclerotherapy on IVF could not be studied. Furthermore, commencement of IVF treatment right after sclerotherapy may have not allowed enough time for the ovaries to recover from the pressure symptoms.

The strength of the present study is the large sample size of the study population. Through thorough examination of medical records, it was possible to analyze the effect of endometrioma aspiration prior to IVF in a group of patients who underwent IVF with the antagonist protocol.

\section{CONCLUSION}

The results of the present study indicate that ethanol sclerotherapy does not improve IVF outcomes when performed right before ovarian stimulation and without concomittant $\mathrm{GnRH}$ analogue administration. However, there is evidence that endometrioma aspiration and ethanol sclerotherapy may be associated with increased anthral follicle counts after 12 months of follow up and that serial endometrioma aspirations improve IVF outcomes when used together with $\mathrm{GnRH}$ analogue treatment. Since previous studies conducted on the subject have varying study designs, it is difficult to reach a consensus on the ideal concentration of ethanol and application method(flushing or retention). Further prospective studies adressing the effect of sclerotherapy on IVF outcomes in special groups of patients with respect to ovarian reserve, endometrioma size, time interval between sclerotherapy and IVF and the concommitant use of $\mathrm{GnRH}$ analogues may help to elucidate the true impact of this treatment on IVF outcomes. Since it is a simple outpatient 
procedure without significant complications, ethanol sclerotherapy may be performed prior to IVF as an alternative to surgery to improve the accessibility of follicles and monitoring of follicle growth in patients with large endometriomas and for those patients with intractable pain symptoms, without decreasing the ovarian reserve.

\section{REFERENCES}

1. D'Hooghe TM, Debrock S, Hill JA, Meuleman C. Endometriosis and subfertility: is the relationship resolved? Semin Reprod Med. 2003 May;21(2):243-54.

2. Ozkan S, Murk W, Arici A. Endometriosis and infertility: epidemiology and evidence-based treatments. Ann N Y Acad Sci. 2008 Apr;1127:92-100.

3. Gupta S, Agarwal A, Agarwal R, Loret de Mola JR. Impact of ovarian endometrioma on assisted reproduction outcomes. Reprod Biomed Online. 2006 Sep;13(3):349-60.

4. Young VJ, Brown JK, Saunders PT, Horne AW. The role of the peritoneum in the pathogenesis of endometriosis. Hum Reprod Update. 2013 Sep-Oct;19(5):558-69

5. Cranney R, Condous G, Reid S. An update on the diagnosis, surgical management, and fertility outcomes for women with endometrioma. Acta Obstet Gynecol Scand. 2017 Jun;96(6):633643.

6. Mahutte NG, Arici A. New advances in the understanding of endometriosis related infertility. J Reprod Immunol. 2002 MayJun;55(1-2):73-83.

7. Al-Azemi M, Bernal AL, Steele J, Gramsbergen I, Barlow D, Kennedy S. Ovarian response to repeated controlled stimulation in in-vitro fertilization cycles in patients with ovarian endometriosis. Hum Reprod. 2000 Jan;15(1):72-5.

8. Kitajima M, Dolmans MM, Donnez O, Masuzaki H, Soares M, Donnez J. Enhanced follicular recruitment and atresia in cortex derived from ovaries with endometriomas. Fertil Steril. 2014 Apr;101(4):1031-7.

9. Donnez J, Binda MM, Donnez O, Dolmans MM. Oxidative stress in the pelvic cavity and its role in the pathogenesis of endometriosis. Fertil Steril. 2016 Oct;106(5):1011-1017.

10. Sanchez AM, Viganò $P$, Somigliana $E$, Panina-Bordignon $P$, Vercellini $\mathrm{P}$, Candiani $\mathrm{M}$. The distinguishing cellular and molecular features of the endometriotic ovarian cyst: from pathophysiology to the potential endometrioma-mediated damage to the ovary. Hum Reprod Update. 2014 Mar-Apr;20(2):217-30.
11. Hsieh CL, Shiau CS, Lo LM, Hsieh TT, Chang MY. Effectiveness of ultrasound-guided aspiration and sclerotherapy with 95\% ethanol for treatment of recurrent ovarian endometriomas. Fertil Steril. 2009 Jun;91(6):2709-13.

12. Wong BC, Gillman NC, Oehninger S, Gibbons WE, Stadtmauer LA. Results of in vitro fertilization in patients with endometriomas: is surgical removal beneficial? Am J Obstet Gynecol. 2004 Aug;191(2):597-606; discussion 606-7.

13. Vercellini $P$, Somigliana E, Viganò $P$, Abbiati A, Barbara $G$, Crosignani $P G$. Surgery for endometriosis-associated infertility: a pragmatic approach. Hum Reprod. 2009 Feb;24(2):254-69.

14. Garcia-Velasco JA, Mahutte NG, Corona J, Zúñiga V, Gilés $\mathrm{J}$, Arici A, Pellicer A. Removal of endometriomas before in vitro fertilization does not improve fertility outcomes: a matched, case-control study. Fertil Steril. 2004 May;81(5):1194-7.

15. Somigliana E, Berlanda N, Benaglia L, Viganò P, Vercellini $P$, Fedele $L$. Surgical excision of endometriomas and ovarian reserve: a systematic review on serum antimüllerian hormone level modifications. Fertil Steril. 2012 Dec;98(6):1531-8.

16. Muzii L, Di Tucci C, Di Feliciantonio M, Marchetti C, Perniola G, Panici PB. The effect of surgery for endometrioma on ovarian reserve evaluated by antral follicle count: a systematic review and meta-analysis. Hum Reprod. 2014 Oct 10;29(10):2190-8.

17. Hamdan M, Dunselman G, Li TC, Cheong Y. The impact of endometrioma on IVF/ICSI outcomes: a systematic review and meta-analysis. Hum Reprod Update. 2015 NovDec;21(6):809-25.

18. Dunselman GA, Vermeulen N, Becker C, Calhaz-Jorge $C$, D'Hooghe T, De Bie B, Heikinheimo O, Horne AW, Kiesel L, Nap A, Prentice A, Saridogan E, Soriano D, Nelen W; European Society of Human Reproduction and Embryology. ESHRE guideline: management of women with endometriosis. Hum Reprod. 2014 Mar;29(3):400-12.

19. Mesogitis S, Daskalakis G, Pilalis A, Papantoniou N, Thomakos N, Dessipris N, Koutra P, Antsaklis A. Management of ovarian cysts with aspiration and methotrexate injection. Radiology. 2005 May;235(2):668-73.

20. Castellarnau Visus M, Ponce Sebastia J, Carreras Collado R, Cayuela Font E, Garcia Tejedor A. Preliminary results: ethanol sclerotherapy after ultrasound-guided fine needle aspiration without anesthesia in the management of simple ovarian cysts. J Minim Invasive Gynecol. 2015 Mar-Apr;22(3):475-82.

21. Gatta G, Parlato V, Di Grezia G, Porto A, Cappabianca S, Grassi R, Rotondo A. Ultrasound-guided aspiration and ethanol 
sclerotherapy for treating endometrial cysts. Radiol Med. 2010 Dec;115(8):1330-9. English, Italian.

22. Albanese G, Kondo KL. Pharmacology of sclerotherapy. Semin Intervent Radiol. 2010 Dec;27(4):391-9.

23. García-Tejedor A, Castellarnau M, Ponce J, Fernández ME, Burdio F. Ethanol sclerotherapy of ovarian en dometrioma: a safe and effective minimal invasive procedure. Preliminary results. Eur J Obstet Gynecol Reprod Biol. 2015 Apr;187:25-9.

24. Yazbeck $C$, Madelenat $P$, Ayel JP, Jacquesson $L$, Bontoux LM, Solal P, Hazout A. Ethanol sclerotherapy: a treatment option for ovarian endometriomas before ovarian stimulation. Reprod Biomed Online. 2009 Jul;19(1):121-5.

25 . Fisch JD, Sher G. Sclerotherapy with $5 \%$ tetracycline is a simple alternative to potentially complex surgical treatment of ovarian endometriomas before in vitro fertilization. Fertil Steril. 2004 Aug;82(2):437-41.

26. Agostini A, De Lapparent T, Collette E, Capelle M, Cravello $L$, Blanc $B$. In situ methotrexate injection for treatment of recurrent endometriotic cysts. Eur J Obstet Gynecol Reprod Biol. 2007 Jan;130(1):129-31.

27. Alpha Scientists in Reproductive Medicine and ESHRE Special Interest Group of Embryology. The Istanbul consensus workshop on embryo assessment: proceedings of an expert meeting. Hum Reprod. 2011 Jun;26(6):1270-83.
28. Gardner, D. \& Schoolcraft, W. (1999). In vitro culture of human blastocysts. Towards reproductive Certainty, Sydney, Australia, Sydney, Australia, pp. 378-388.

29. Cohen A, Almog B, Tulandi T. Sclerotherapy in the management of ovarian endometrioma: systematic review and meta-analysis. Fertil Steril. 2017 Jul;108(1):117-124.e5.

30. Aflatoonian A, Rahmani E, Rahsepar M. Assessing the efficacy of aspiration and ethanol injection in recurrent endometrioma before IVF cycle: A randomized clinical trial. Iran J Reprod Med. 2013 Mar;11(3):179-84.

31. Guo YH, Lu N, Zhang Y, Su YC, Wang Y, Zhang YL, Sun YP. Comparative study on the pregnancy outcomes of in vitro fertilization-embryo transfer between long-acting gonadotropin-releasing hormone agonist combined with transvaginal ultrasound-guided cyst aspiration and long-acting gonadotropin-releasing hormone agonist alone. Contemp Clin Trials. 2012 Nov;33(6):1206-10.

32. Miquel L, Preaubert L, Gnisci A, Resseguier N, Pivano A, Perrin J, Courbiere B. Endometrioma ethanol sclerotherapy could increase IVF live birth rate in women with moderate-severe endometriosis. PLoS One. 2020 Sep 28;15(9):e0239846. 